\title{
Você pode não ser um atleta, mas tem muito a ganhar neste jogo! \\ As oportunidades que os megaeventos esportivos podem gerar para os profissionais de comunicação e relações públicas
}

You may not be an athlete, but you have much to achieve from this game! The opportunities that sports mega-events can generate for communication and public relations professionals

Puedes no ser un atleta, pero tienes mucho que ganar en este partido!

Las oportunidades que los megaeventos deportivos pueden generar para los profesionales de comunicación y relaciones públicas

Vania Ciorlia ${ }^{1}$

Futura sede de três dos principais eventos esportivos do planeta - a Copa do Mundo de Futebol, em 2014, e os Jogos Olímpicos e Paraolímpicos, em 2016 -, o Brasil se apresenta hoje como um cenário de grandes oportunidades de negócios para as empresas que desejem trabalhar sua comunicação vinculada ao esporte.

Esse momento único para a história do país é também um marco para nós, comunicadores, e para nossos clientes, que têm a chance de ampliar a visibilidade e o awareness de suas marcas, produtos e serviços, gerando tendências

1 Formada em Jornalismo e Editoração pela Universidade de São Paulo, é diretora executiva da Ketchum e responde pela área de Comunicação Integrada. Possui ampla experiência com grandes corporações e marcas em imprensa, eventos e planejamento estratégico de comunicação integrada com foco em resultados de imagem, branding e reputação. Foi editora assistente da Veja São Paulo por cinco anos. Ex-atleta da seleção brasileira juvenil de basquete, já realizou vários trabalhos de relações públicas em esporte, como o lançamento do tênis Tiger no Brasil, a divulgação de torneios internacionais de tênis da Koch Tavares e, mais recentemente, o plano de branding para o time de futebol Figueirense, de Santa Catarina. É responsável também pela implantação da Ketchum Sports \& Entertainment (KSE) no Brasil. E.mail: vania.ciorlia@ketchum.com.br. 
e estreitando relacionamentos por meio de ações ligadas ao esporte e ao entretenimento.

O mercado está aquecido. A cada dia surgem novas agências de marketing esportivo e inúmeros projetos below the line, explorando o potencial das mídias sociais e a interatividade. Atletas são eleitos embaixadores de marcas, assinam contratos milionários para representar determinados produtos e, a partir daí, começa o estado de alerta.

O que a personalidade esportiva sabe sobre o produto que representa? O quanto sua vida pessoal condiz com os atributos da marca que carrega em seu uniforme? Ela sabe se portar diante das câmeras em uma entrevista ou quando está em público? Tem ideia do que pode ou não tuitar ou publicar em sua página no Facebook? Consegue entender que um simples comentário ou foto podem pôr a perder grandes investimentos em branding? Imagina o estrago que um passo em falso pode causar ao seu patrocinador?

Se antes treinávamos os executivos e CEOs em media trainings que os preparavam para o contato com a imprensa, hoje temos muito mais a fazer. Com o esporte ganhando espaço de destaque nos diferentes veículos, contratantes e contratados têm de estar prontos para lidar com o universo on e off-line. E com as crises, que nascem e crescem numa velocidade assustadora. Afinal, milhões de reais e a reputação corporativa podem estar em jogo. Mapear riscos e cenários, desenvolver planos de prevenção e gerenciamento dessas crises, aplicar treinamento digital são apenas uma pequena amostra do que é possível fazer em relações públicas no esporte.

Nos últimos anos grandes marcas esportivas como Nike, Reebook, Puma, Asics, Mizuno, Adidas, Rainha e Topper realizaram campanhas de comunicação bem-sucedidas no Brasil. Acompanhei de perto alguns cases interessantes, como a recente divulgação feita para o Figueirense Futebol Clube, focada não nos resultados ou nos integrantes do time, mas na profissionalização de sua administração e no plano de longo prazo por ela traçado, cuja primeira consequência imediata foi a subida da equipe para a primeira divisão do Campeonato Brasileiro de Futebol. Mais do que esporte, aqui o enfoque era gestão e negócios. Foram muitas matérias retratando o clube e seu potencial, em veículos de repercussão nacional, como os jornais Valor Econômico e O Globo, a TV Globo etc.

Esporte e comunicação também formam excelente parceria para ações de relacionamento. Um bom exemplo é o projeto desenvolvido para a Caloi durante quatro anos, na década passada. Mais do que divulgar o patrocínio do circuito Caloi Adventure Camp, o objetivo era tornar a corrida de aventura conhecida, divulgando o esporte para diferentes públicos, atraindo novos praticantes e gerando visibilidade para a marca, além de associá-la à natureza e a uma vida saudável. Pesquisar sobre o tema e conversar com atletas praticantes 
não era suficiente. Para falar do assunto com propriedade e transmitir aos jornalistas o entusiasmo necessário, era preciso vivência. Para isso a equipe de comunicação responsável pela campanha "degustou" antecipadamente o evento, aprendendo todas as modalidades esportivas que fazem parte da corrida de aventura. A partir daí e do próprio tema os foram "contaminados" com o espírito de aventura, com isso, a campanha teve excelentes resultados. Quando o trabalho foi iniciado, participavam do evento cerca de 240 atletas. Após dez provas, esse número dobrou, chegando a quinhentas pessoas inscritas em uma única prova. Foram mais de oitenta jornalistas "Praticando Caloi" e mais de cem matérias publicadas, nos mais importantes veículos de comunicação do país. Prova de que uma ação de relações públicas bem planejada e executada se traduz em ferramenta de marketing, com retornos positivos de imagem para a marca que hoje é reconhecida no segmento de esportes de aventura.

Outro exemplo de casamento entre comunicação e esportes é o case da Lenovo, patrocinadora da Olimpíada de Beijing e da Caminhada da Tocha Olímpica por catorze países. Nesse caso, a comunicação da marca foi feita com base em um plano de RP 360 graus, que englobou guia de crise, preparação de materiais, treinamento de porta-vozes, lounges espalhados por diferentes locais com exposição de produtos altamente ligados à tecnologia, blog, campanha de orgulho e pertencimento para os funcionários com concurso interno que elegeu representantes para carregarem a tocha ao lado de celebridades e atletas famosos, contratação de embaixadores da marca que elegiam entidades para receberem doação de equipamentos, além da montagem de um centro de tecnologia de informação para o acesso de atletas e da imprensa no período dos jogos, entre outras ações. Durante os jogos, a frequência ao site de compras da empresa aumentou em $75 \%$ e a busca pela marca no Google, em 40\%. E o awareness da marca Lenovo cresceu de $21 \%$ para $29 \%$ no pós-Olimpíada.

E como não lembrar o sucesso de uma ação de comunicação ligada ao esporte sem citar o case de Doritos? A marca convidou internautas a criar um vídeo sobre Doritos bom o suficiente para ser veiculado durante o intervalo do Super Bowl, a grande final do futebol norte-americano, um dos espaços comerciais mais caros do mundo! O tema era livre e a escolha foi feita por um júri de indicados pela empresa patrocinadora e pelos internautas, que poderiam se registrar no site oficial do desafio, assistir aos finalistas e votar no seu favorito. De 2007 a 2010, a marca deixou seu espaço publicitário milionário, no evento mais assistido nos Estados Unidos, nas mãos de seus fãs, consumidores, produtores, diretores e criativos em geral. Foram mais de 7 mil vídeos registrados e 5,2 bilhões de pages views no período. O primeiro comercial escolhido custou doze dólares para ser produzido, tendo sido veiculado em um spot de trinta segundos com valor de 2,6 milhões de dólares. A repercussão desse vídeo na internet, após o Super Bowl, rendeu à Doritos o equivalente a 36 milhões de dólares em investimento de mídia. Considerando que, na verdade, a marca só investiu 2,6 milhões mais os 10 mil dólares dados ao vencedor, dá para perceber o poder da comunicação e do usuário conectado de hoje. Em 2011, o 
prêmio já é de 1 milhão de dólares para o vencedor. Esse trabalho foi eleito em 2010 como a melhor campanha de relações públicas da década pelo The Holmes Report, grupo internacional dedicado ao desenvolvimento das relações públicas e ao reconhecimento dos profissionais que atuam na área.

Copas e olimpíadas são excelentes oportunidades para campanhas internas de incentivo e engajamento de colaboradores, além de orgulho de pertencimento. A Dow percebeu que o patrocínio dos Jogos Olímpicos até 2020 era uma boa oportunidade de estreitar a relação com seus funcionários. No dia do anúncio do patrocínio, entregou a cada colaborador um cordão de crachá com o símbolo olímpico, e durante o dia eles receberam a visita do quarteto olímpico formado pelos atletas Flávio Canto, Natália Falavigna, Leila e Emmanuel. As estrelas do esporte distribuíram cartões postais autografados, pins com o logo olímpico e tiraram fotos com todos. Em paralelo, foi realizado no auditório da empresa um seminário para cliente,s com a presença do CEO mundial da Dow e do CEO dos Jogos Olímpicos de 2016, mais os atletas olímpicos Giovani e Maurren Maggi. Ao final do evento, um coquetel reuniu convidados, atletas e funcionários em um ambiente descontraído, onde um painel era preenchido com mensagens sobre esse dia de ouro para a Dow.

Dados da Academia Brasileira de Marketing Esportivo (Abraesporte) indicam que o marketing esportivo já movimenta cerca de R\$ 15 bilhões por ano no Brasil, número que, segundo seu presidente, José Estevão Cocco, deverá triplicar até a Copa de 2014. "Mas o mercado precisa entender que esse marketing esportivo vai muito além do patrocínio. Temos inúmeras ferramentas que podem e devem ser trabalhadas durante a copa e a olimpíada”. Esse é um filão a ser explorado por nós, profissionais de comunicação e relações públicas. Vai subir ao pódio quem tiver as big ideas e souber explorar melhor as ações de relacionamento com os diferentes stakeholders. 